\title{
Karakterisasi dan Klasifikasi Ultisols Yang Berkembang dari Dua Bahan Induk di Kabupaten Serang, Provinsi Banten
}

\author{
Mahfud Arifin $^{1}$, Ganjar Herdiansyah ${ }^{2}$, Apong Sandrawati ${ }^{1}$, Rina Devnita ${ }^{1}$ \\ ${ }^{1}$ Staff Pengajar Departemen Ilmu Tanah dan Sumberdaya Lahan, Fakultas Pertanian, Unpad \\ ${ }^{2}$ Staff Pengajar Program Studi Ilmu Tanah, Fakultas Pertanian, UNS
}

Korespondensi: mahfud.arifin@unpad.ac.id

\begin{abstract}
The effort to utilize the soils optimally, especially Ultisols, requires an appropriate understanding related to their characteristics. The characteristics of Ultisols are sturdily influenced by soil-forming factors, viz. climate, parent material, pedogenic age and topography. The purposes of this study were to determine the chemical, physical, mineralogical characteristics and soil development classification level of Ultisol from two different types of parent rock. This research was conducted in Kampungbaru Village, Petir District and Sukalaksana Village, Curug District, in Serang Regency, Banten Province. These two villages represented different parent materials, namely andesite lava parent material of Holocene age (Kampungbaru Village) and tuff dacite parent material of early Pleistocene age (Sukalaksana Village). The research method was descriptive, comparative and survey. Soil classification was based on the Soil Survey Staff. The results showed that Ultisols developed from dacite tuff and andesite lava did not show contrasting differences in soil properties. The level of weathering of the two pedons was at the senile stage and the level of soil development of the two pedons was at the argillic stage. The soil classification of Kampungbaru pedon was Typic Palehumults, very fine, kaolinitic, isohyperthermic, while the Sukalaksana pedons was Arenic Paleudults, fine, kaolinitic, isohyperthermic.
\end{abstract}

Keywords: parent material, Ultisols, soil characteristics, soil classification.

\section{PENDAHULUAN}

Ultisol merupakan salah satu ordo tanah dengan sebaran yang luas dengan sebaran $25 \%$ dari luas daratan Indonesia atau \pm 45 juta hektar (Subagyo dkk., 2004). Ordo tanah ini dicirikan oleh tingkat perkembangan tanah yang sudah lanjut. Hal ini dapat dicirikan dengan pembentukkan akumulasi liat pada horizon B yang disebut horozon penciri argilik (Soil Survey Staff, 2014). Pada klasifikasi nasional Ultisol diklasifikasikan sebagai Podsolik dengan penciri plintit pada kedalaman $125 \mathrm{~cm}$ dari permukaan tanah (Subardja dkk., 2006).

Ultisol dapat terbentuk dari berbagai jenis batuan induk tua (Hardjowigeno, 2003). Sebagian besar Ultisol di Indonesia terbentuk dari bahan induk sedimen (Pusat Penelitian Tanah dan Agroklimat, 2000) yang berasal dari batuan liat (Hardjowigeno, 2003).

Pada pemanfaatan untuk pertanian, karakteristik khas Ultisols sangat dipertimbangkan. Tanah-tanah ini umumnya mempunyai nilai $\mathrm{pH}$ yang masam dengan kejenuhan $\mathrm{Al}$ yang tinggi. Hal ini berdampak kepada ketersediaan $\mathrm{P}$, kation-kation basa lain $(\mathrm{Ca}, \mathrm{Mg}$, $\mathrm{K}$, dan $\mathrm{Na}$ ) menjadi sangat rendah (Adiningsih dan Mulyadi, 1993 dalam Subagyo dkk., 2004). Permasalahan ini menjadikan Ultisol belum dimanfaatkan secara optimal. Di Indonesia sendiri Ultisol sebagian besar digunakan sebagai untuk perkebunan dan hutan tanaman industri (Prasetyo dan Suriadikarta, 2006).

Berdasarkan Peta Geologi Lembar Serang (1991), sebagian besar umur batuan induk adalah quarter. Bahan penyusun batuan induk (formasi geologi) sangat beragam dari mulai bahan aluvial atau endapan sungai (Qa), tufaan dan batu apung (Qpvb), endapan breksi dan lahar (Qpvm), endapan breksi lahan dan konglomerat (Qpvk), dsb. Formasi geologi ini menghasilkan keragaman bahan induk tanah yang tinggi. Walaupun bahan induk beragam, dengan proses pelapukan dan tingkat perkembangan lanjut, bahan-bahan induk tersebut akan menghasilkan tanah-tanah tua seperti Ultisol. 
Perbedaan batuan induk tentunya menyebabkan perbedaan karakteris-tik tanah yang terbentuk. Ultisol yang terbentuk dari bahan induk volkan dan batu gamping akan mempunyai tingkat kesuburan tanah yang lebih tinggi daripada Ultisol yang terbentuk dari batuan sedimen (Prasetyo dan Suriadikarta, 2006).

\section{METODE PENELITIAN}

\subsection{Lokasi Penelitian}

Secara administratif, lokasi penelitian berada di 2 (dua) kecamatan yakni Kecamatan
Kecamatan Petir dan Kecamatan Curug, Kabupaten Serang, Provinsi Banten (Gambar 1). Profil pertama (Pedon 1) terletak di wilayah Desa Kampung Baru, Kecamatan Petir, dan Profil kedua (Pedon 2) terletak di Desa Sukalaksana Kecamatan Curug.

Penetapan lokasi berdasarkan keterwakilan jenis tanah dan bahan induk. Lokasi penelitian diklasifikasikan kepada Ultisol atau Podsolik. Kedua lokasi mewakili karakteristik bahan induk yang berbeda, yaitu: tufa dasit (Pedon 1) dan bahan induk produk Gunung Api Karang (Pedon 2).

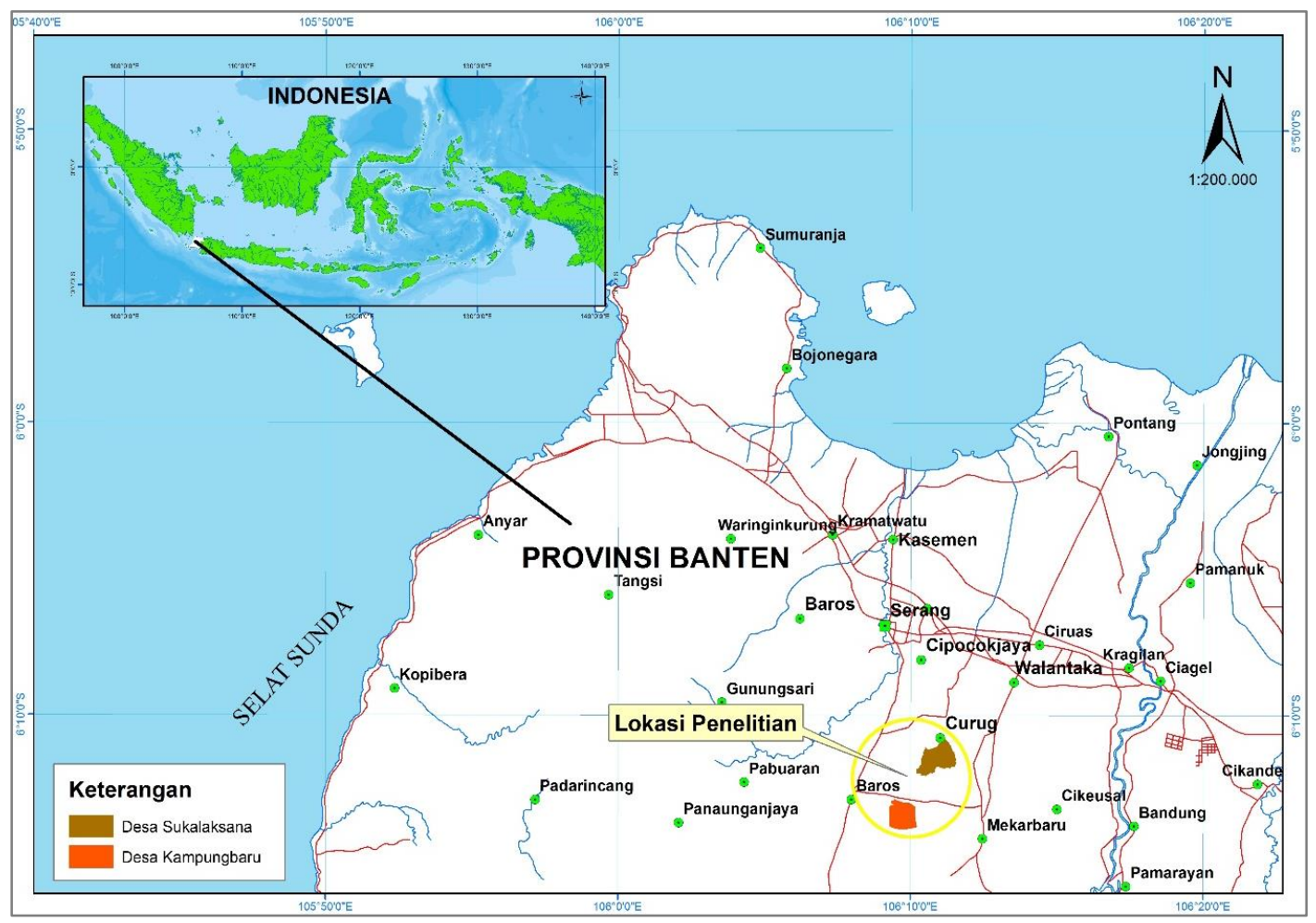

Gambar 1 Lokasi Penelitian

Bahan induk penyusun tanah terdiri atas formasi batuan Gunung Api Karang (Qvk) di wilayah Kecamatan Petir, dan formasi batuan tufaan dan batu apung (Qpvb) di wilayah Kecamatan Curug (Gambar 2). Formasi Qvk dan Qpvb berkembang dari bahan vulkanik. Formasi Qvk merupakan produk Gunung Api Karang yang bersifat andesitik dan basalt, sedangkan formasi Qpvb merupakan batuan gunung api tua.

\subsection{Analisis Sifat Tanah}

Metode dan prosedur pengamatan dan pengambilan sampel tanah mengacu kepada Soil Survey Staff (2014). Analisis laboratorium meliputi analisis fisika tanah di laboratorium fisika tanah Fakultas Pertanian UNPAD, analisis kimia di laboratorium tanah Balai Penelitian Tanaman Sayuran (Balitsa), analisis mineralogi di laboratorium mineralogi Balai Penelitian Tanah. 


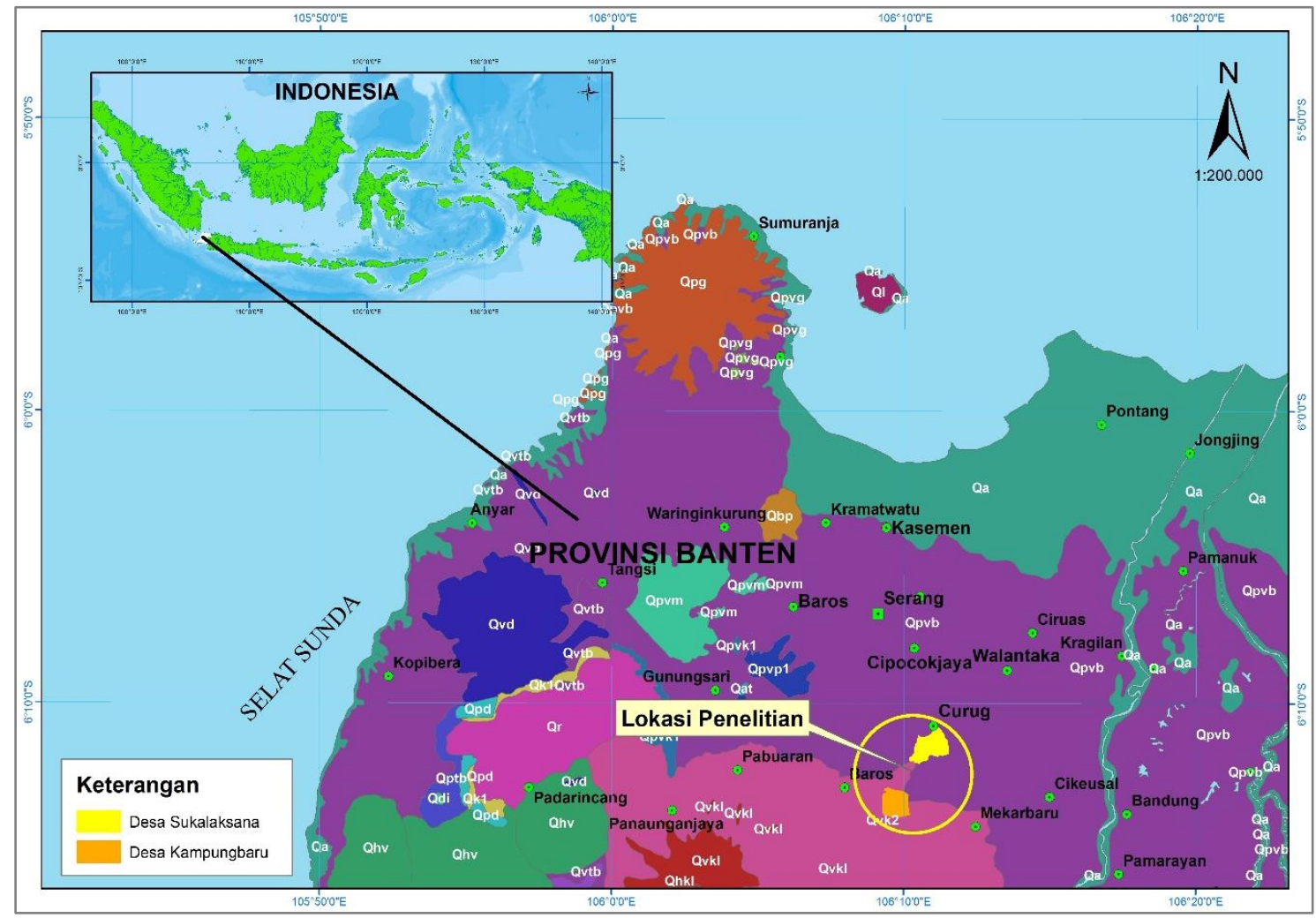

Gambar 2 Peta Geologi Lokasi Penelitian

Analisis laboratorium untuk parameter tekstur, $\mathrm{pH} \mathrm{H}_{2} \mathrm{O}, \mathrm{pH} \mathrm{KCl}$, c-organik, kationkation, KTK, H-dd dan Al-dd, mengacu kepada Van Reeuwijk, (2002). Analisis mineral liat dengan analisis XRD (Brown, 1980). Analisis bobot isi menggunakan metode gravimetri dari ring sampler. Analisis permeabilitas tanah mengacu kepada metode Constant Head Permeameter.

\section{HASIL DAN PEMBAHASAN}

\subsection{Sifat Morfologi Tanah}

Sifat morfologi tanah yang diamati meliputi warna tanah, tekstur, sturktur, konsistensi, batas horison, pori-pori serta bahan kasar. Hasil analisis sifat morfologi tanah pada kedua Pedon disajikan pada Tabel 1.

Hasil pengamatan warna tanah pada profil Kampungbaru (Pedon 1) berkisar antara coklat tua (7,5 YR 3/4) sampai merah (2,5 YR 4/8). Pada horison permukaan (A) didapatkan warna tanah yang lebih gelap dibandingkan dengan horison dibawahnya (B). Horison Bt1 sampai Bt5 menunjukkan warna tanah merah kekuningan, semakin bertambahnya kedalaman warna berubah secara teratur menjadi merah. Profil Sulaksana (Pedon 2) menunjukkan warna tanah berkisar dari coklat tua sampai merah kekuningan. Pada horison permukaan (AP) berwarna coklat tua (7,5 YR 3/2) semakin bertambahnya kedalaman warna tanah berubah secara berangsur menjadi merah kekuningan (5 YR 4/6).

Berdasarkan warna tanahnya, kedua pedon memiliki kisaran warna yang hampir sama yaitu dari coklat sampai merah. Pedon 1 secara relatif memperlihatkan kecenderungan agak merah dibandingkan dengan Pedon 2. Warna tanah yang cenderung merah dapat disebabkan oleh kandungan besi oksida (Schwertmann and Taylor, 1989 dalam Prasetyo, 2009). Mineral oksida besi dihasilkan dari pelepasan Fe dari mineral primer selama pelapukan tanah (Prasetyo, 2009). 
Tabel 1 Sifat Morfologi Tanah Pada Pedon Kampungbaru dan Sukalaksana

\begin{tabular}{|c|c|c|c|c|c|c|c|c|c|}
\hline Pedon & Horison & Kedalaman & $\begin{array}{c}\text { Batas } \\
\text { Horison }\end{array}$ & $\begin{array}{l}\text { Warna } \\
\text { Tanah }\end{array}$ & Tekstur & Struktur & $\begin{array}{c}\text { Konsistens } \\
\text { i }\end{array}$ & Pori-pori & $\begin{array}{c}\text { Bahan } \\
\text { Kasar }\end{array}$ \\
\hline \multirow{7}{*}{$\begin{array}{c}\text { Kampung } \\
\text { baru } \\
\text { (Pedon } 1)\end{array}$} & A & $0-14$ & jelas, rata & 7,5YR 3/4 & sic & sbk, f, 2 & f,s,sp,h & $\mathrm{i} ; \mathrm{m}$ & $\begin{array}{c}\text { sedikit, } \\
\text { kerikil, } \\
\text { halus }\end{array}$ \\
\hline & $\mathrm{BA}$ & $14-28$ & $\begin{array}{c}\text { berangsur, } \\
\text { rata }\end{array}$ & 5YR $3 / 4$ & sic & skb, f, 2 & f,s,sp,h & $e ; f$ & $\begin{array}{c}\text { sedikit, } \\
\text { kerikil, } \\
\text { halus }\end{array}$ \\
\hline & Bt1 & $28-59$ & jelas & 5YR 4/6 & c & abk, f, 2 & f,s,p,h & $\mathrm{i} ; \mathrm{f}$ & - \\
\hline & $\mathrm{Bt} 2$ & 59-85 & $\begin{array}{c}\text { berangsur, } \\
\text { rata }\end{array}$ & 2,5YR 3/6 & c & abk, f, 3 & vt,vs,h & $\mathrm{i} ; \mathrm{f}$ & - \\
\hline & Bt3 & $85-114$ & $\begin{array}{c}\text { berangsur, } \\
\text { rata }\end{array}$ & $2,5 Y R 4 / 6$ & c & abk, f, 3 & vt,vs,h & $\mathrm{i} ; \mathrm{f}$ & $\begin{array}{c}\text { sedikit, } \\
\text { kerikil, } \\
\text { halus }\end{array}$ \\
\hline & Bt4 & $114-150$ & $\begin{array}{c}\text { berangsur, } \\
\text { rata }\end{array}$ & 2,5YR 4/8 & $\mathrm{c}$ & abk, f, 3 & vt,vs,h & $\mathrm{i} ; \mathrm{f}$ & $\begin{array}{c}\text { sedikit, } \\
\text { kerikil, } \\
\text { halus }\end{array}$ \\
\hline & Bt5 & $150-200$ & $\begin{array}{c}\text { berangsur, } \\
\text { rata }\end{array}$ & 2,5YR 4/8 & c & abk, f, 3 & vt,vs,h & $\mathrm{i} ; \mathrm{f}$ & $\begin{array}{c}\text { sedikit, } \\
\text { kerikil, } \\
\text { halus }\end{array}$ \\
\hline \multirow{5}{*}{$\begin{array}{c}\text { Sukalaksana } \\
\text { (Pedon 2) }\end{array}$} & Ap & $0-15$ & $\begin{array}{l}\text { berangsur, } \\
\text { berombak }\end{array}$ & 7,5YR 3/2 & $\mathrm{cl}$ & $a b k, f, 2$ & f,ss,sp & i,e,a; m & - \\
\hline & $\mathrm{BA}$ & $15-38$ & $\begin{array}{c}\text { berangsur, } \\
\text { berombak }\end{array}$ & 7,5YR 4/6 & $\mathrm{cl}$ & abk, f, 2 & $\mathrm{f}, \mathrm{s}, \mathrm{p}$ & i,e; m,a; f & - \\
\hline & Bt1 & $38-75$ & $\begin{array}{c}\text { berangsur, } \\
\text { berombak }\end{array}$ & $5 Y R 3 / 4$ & c & abk, f, 2 & $\mathrm{f}, \mathrm{s}, \mathrm{vp}$ & $\begin{array}{c}\mathrm{i} ; \mathrm{f}, \mathrm{e} ; \mathrm{m}, \mathrm{a} ; \\
\mathrm{m}\end{array}$ & - \\
\hline & Bt2 & $75-126$ & $\begin{array}{c}\text { berangsur, } \\
\text { berombak }\end{array}$ & 7,5YR 4/4 & c & abk, f, 2 & vt,s,vp & $\begin{array}{c}\mathrm{i} ; \mathrm{c}, \mathrm{e} ; \mathrm{m}, \mathrm{a} ; \\
\mathrm{c}\end{array}$ & - \\
\hline & Bt3 & $126-200$ & $\begin{array}{c}\text { jelas, } \\
\text { berombak }\end{array}$ & $5 Y R 4 / 6$ & c & abk, f, 2 & $\mathrm{f}, \mathrm{ss}, \mathrm{p}$ & $\begin{array}{c}\mathrm{i} ; \mathrm{c}, \mathrm{e} ; \mathrm{m}, \mathrm{a} ; \\
\mathrm{c}\end{array}$ & - \\
\hline
\end{tabular}

Keterangan :

Struktur : : sbk (gumpal membulat), abk (gumpal bersudut), f (ukuran halus)

Konsistensi : f (gembur), s (lekat), ss (agak lekat), p (plastis), sp (agak plastis), vt (sangat teguh), vp (sangat plastis).

Pori-pori : i (mikro), e (meso), a (makro), f (sedikit), m (cukup), c (banyak).

Hasil pengamatan tekstur di lapangan menunjukkan bahwa kedua pedon umumnya memiliki tekstur liat, walaupun pada horison permukaan didapatkan tekstur liat berdebu dan lempung berliat. Penjelasan tekstur lebih lanjut diuraikan pada sub-bahasan sifat fisika tanah.

Hasil pengamatan struktur tanah di lapangan menunjukkan bahwa kedua pedon memiliki struktur gumpal bersudut (angular blocky) berukuran halus dengan tingkat perkembangan sedang sampai kuat. Perbedaan hasil pengamatan ini perbedaan bahan induk tidak memperlihatkan perbedaan struktur yang jelas. Hasil pengamatan struktur ini sama dengan pengamatan konsistensi dimana perbedaan sifat bahan induk kurang memperlihatkan perbedaan konsistensi yang tegas.
Batas horison pada kedua pedon bervariasi antara berangsur sampai jelas dengan topografi rata sampai berombak. Batas peralihan umumnya jelas sampai berangsur dan tidak ditemukan batasan peralihan yang sangat jelas. Perbedaan bahan induk tidak menunjukan adanya perbedaan yang jelas pada batas horison. Baurnya perbedaan horison ini lazim terjadi pada tanah-tanah yang sudah berkembang sangat lanjut.

Hasil pengamatan menunjukkan bahwa terdapat bahan kasar dalam fraksi tanah pada Pedon 1, sedangkan pada pedon 2 tidak ditemukan bahan kasar. Perbedaan ini diduga dipengaruhi oleh umur pedogenic Pedon 2 yang sudah lanjut, sehingga fragmen batuan telah terlapuk. Bahan kasar ini berupa fragmen batuan hasil kegiatan magmatik (lafili) atau 
fragmen batuan yang berasal dari dinding keldera yang terlempar saat erupsi. Hal tersebut terjadi pada pedon 1. Jarak yang lebih dekat dengan Gunung Karang diduga menjadi penyebab fraksi kasar tanah yang ditemukan lebih banyak dari Pedon 1.

\subsection{Sifat Fisika Tanah}

Pada horison permukaan Pedon 1, ukuran partikelnya didominasi oleh fraksi debu (47,65\%), hal ini karena adanya penambahan bahan dipermukaan dari bahan induk non liat, mengingat pedon ini berada pada lereng yang dekat dengan Gunung Karang (bahan induk non liat). Distribusi partikel pada horison bawahnya secara kontras didominasi oleh fraksi liat dengan peningkatan (akumulasi) secara drastis.hal ini menunjukkan bahwa pedon yang diteliti telah mengalami perkembangan lanjut. Pada Pedon 2 distribusi partikel didominasi oleh fraksi liat. Hal Ini diduga jenis bahan induk pedon tersebut yang mempengaruhi, dimana bahan induk pedon ini adalah bahan induk batuan liat yang berumur tua (tufa dasit) serta sudah mengalami perkembangan lanjut. Besar ukuran butir disajikan pada Tabel 2 .

Tabel 2 Distribusi ukuran partikel Tanah pada Pedon Kampungbaru dan Sukalaksana

\begin{tabular}{|c|c|c|c|c|c|c|c|c|c|c|}
\hline \multirow[t]{2}{*}{ Pedon } & \multirow[t]{2}{*}{ Horison } & \multirow{2}{*}{$\begin{array}{l}\text { Kedalaman } \\
\quad(\mathrm{cm})\end{array}$} & Pasir & Debu & $\begin{array}{c}\text { Liat } \\
\text { Kasar }\end{array}$ & $\begin{array}{c}\text { Liat } \\
\text { Halus } \\
\end{array}$ & $\begin{array}{c}\text { Liat } \\
\text { Total }\end{array}$ & \multirow[t]{2}{*}{$\mathrm{DT} / \mathrm{LT}$} & \multirow[t]{2}{*}{$\mathrm{DH} / \mathrm{LT}$} & \multirow[t]{2}{*}{ LH/LT } \\
\hline & & & \multicolumn{5}{|c|}{ - } & & & \\
\hline \multirow{7}{*}{$\begin{array}{c}\text { Kampung Baru } \\
\text { (Pedon 1) }\end{array}$} & $\mathrm{A}$ & $0-14$ & 10,23 & 47,66 & 14,75 & 27,35 & 42,11 & 1,10 & 0,44 & 0,65 \\
\hline & $\mathrm{BA}$ & $14-28$ & 11,59 & 37,98 & 13,57 & 36,83 & 50,43 & 0,75 & 0,27 & 0,73 \\
\hline & Bt1 & $28-59$ & 3,78 & 11,83 & 4,67 & 79,72 & 84,39 & 0,14 & 0,04 & 0,94 \\
\hline & Bt2 & $59-85$ & 6,19 & 5,35 & 3,07 & 85,39 & 88,46 & 0,06 & 0,06 & 0,96 \\
\hline & $\mathrm{Bt} 3$ & $85-114$ & 11,10 & 12,06 & 3,92 & 72,92 & 76,84 & 0,16 & 0,03 & 0,95 \\
\hline & Bt4 & $114-150$ & 1,51 & 9,28 & 8,08 & 82,13 & 89,21 & 0,10 & 0,01 & 0,91 \\
\hline & $\mathrm{Bt} 5$ & $150-200$ & 3,33 & 16,14 & 12,56 & 67,93 & 80,53 & 0,20 & 0,11 & 0,84 \\
\hline \multirow{5}{*}{$\begin{array}{c}\text { Sukalaksana } \\
\text { (Pedon 2) }\end{array}$} & $\mathrm{Ap}$ & $0-15$ & 14,72 & 31,87 & 11,90 & 41,51 & 53,41 & 0,60 & 0,24 & 0,78 \\
\hline & BA & $15-38$ & 10,80 & 22,07 & 15,54 & 51,59 & 67,13 & 0,33 & 0,14 & 0,77 \\
\hline & Bt1 & $38-75$ & 7,55 & 9,11 & 11,54 & 71,80 & 83,34 & 0,11 & 0,05 & 0,86 \\
\hline & Bt2 & $75-126$ & 2,19 & 8,42 & 6,74 & 82,65 & 89,39 & 0,09 & 0,03 & 0,92 \\
\hline & Bt3 & $126-200$ & 2,13 & 7,26 & 8,40 & 82,04 & 90,44 & 0,08 & 0,04 & 0,91 \\
\hline
\end{tabular}

Keterangan: DT: Debu Total; DH: Debu Halus; LT: Liat Total; LH: Liat Halus.

Pengamatan bobot isi tanah dilakukan pada kedalaman 0-30 cm (lapisan I) dan 30-60 cm (lapisan II). Pada Tabel 4 hasil analisis bobot isi menunjukkan Pedon Kampungbaru pada lapisan I sebesar 1,15 g/cc dan di lapisan II sebesar 1,18 g/cc. BD lapisan I lebih kecil daripada lapisan II, hal ini terjadi karena adanya pengolahan tanah, sehingga terjadi penggemburan pada lapisan I. Begitupun pada Pedon Sukalaksana, terjadi pengolahan tanah yang menyebabkan nilai BD lapisan I lebih kecil daripada lapisan II.

Hasil pengukuran permeabilitas kedua pedon menunjukkan nilai yang rendah. Pedon Sukalaksana memiliki permeabilitas lebih rendah dibandingkan dengan Pedon Kampungbaru, hal ini sejalan dengan tingginya kandungan liat pada pedon tersebut. Proses pelapukan yang berlangsung lebih lama mengakibatkan berkurangnya fraksi pasir, debu serta bahan organik.

Tabel 3 Bobot Isi (Bulk Density) dan Permeabilitas

\begin{tabular}{ccrr}
\hline Pedon & Kedalaman & $\begin{array}{c}\text { Bobot } \\
\text { Isi } \\
(\mathrm{g} / \mathrm{cc})\end{array}$ & $\begin{array}{c}\text { Permeabilitas } \\
(\mathrm{cm} / \mathrm{jam})\end{array}$ \\
\hline Kampung & $0-30 \mathrm{~cm}$ & 1,15 & 0,54 \\
Baru & $30-60 \mathrm{~cm}$ & 1,18 & 0,59 \\
Sukalaksana & $0-30 \mathrm{~cm}$ & 1,21 & 0,20 \\
& $30-60 \mathrm{~cm}$ & 1,38 & 0,76 \\
\hline
\end{tabular}


Tinggi rendahnya permeabilitas berhubungan dengan kandungan debu dan liat. Ini diduga berkaitan dengan tingkat pelapukan yang terjadi pada tanah Ultisol, makin lanjut tingkat pelapukan, maka fraksi pasir akan berubah menjadi fraksi yang lebih halus.

\subsection{Sifat Kimia Tanah}

Sifat kimia yang diamati yaitu $\mathrm{pH}$, kationkation basa, kemasaman terekstrak, c-organik, KTK, retensi $\mathrm{P}$, retensi Fe. Hasil analisis laboratorium terhadap sifat kimia tanah dapat dilihat pada Tabel 4. Hasil analisis terhadap $\mathrm{pH}$ tanah Pedon 1 memiliki pH yaitu 5,5 sampai 5,9 dan terlihat terjadinya peningkatan seiring bertambahnya kedalaman tanah. Pedon 2 memiliki pH yaitu 5,5 sampai 5,8. Pedon 1 memiliki rata-rata $\mathrm{pH}$ lebih tinggi daripada Pedon 2, hal ini diduga karena sifat bahan induk dari pedon 1 lebih bersifat basaltik.

Nilai pH KCl kedua pedon yaitu 4,1 - 4,7. Nilai $\mathrm{pH} \mathrm{KCl}$ yang lebih rendah dari $\mathrm{pH} \mathrm{H}_{2} \mathrm{O}$ menunjukkan terdapat sejumlah $\mathrm{Al}$ dapat ditukar, menurunnya $\mathrm{pH}$ dengan $\mathrm{KCl}$ ini karena akibat hidrolisis dari Al diganti oleh K. Tanahtanah dengan perkembangan lanjut memiliki pH (KCl) lebih kecil dibandingkan dengan tanah muda, hal ini akibat dari adanya muatan permanen pada tanah tua, dimana mineralmineralnya sudah berkembang menjadi mineral liat kristalin (kaolinit).

Tabel 4 Sifat Kimia Tanah pada Pedon Kampungbaru dan Sukalaksana

\begin{tabular}{|c|c|c|c|c|c|c|c|c|c|c|c|}
\hline \multirow{2}{*}{ Pedon } & \multirow{2}{*}{ Horison } & \multirow{2}{*}{$\begin{array}{c}\text { Kedalaman } \\
(\mathrm{cm})\end{array}$} & \multicolumn{2}{|c|}{$\mathrm{pH}$} & \multirow{2}{*}{$\begin{array}{c}\text { C-Org } \\
\% \\
\end{array}$} & \multirow{2}{*}{\multicolumn{2}{|c|}{$\begin{array}{cc}\mathrm{Ca} \quad \mathrm{Mg} \\
------\mathrm{cmol} / \mathrm{kg}\end{array}$}} & \multirow{2}{*}{ KTK } & \multirow{2}{*}{$\begin{array}{c}\mathrm{KB} \\
\% \\
\end{array}$} & \multirow{2}{*}{$\begin{array}{c}\mathrm{FeO}_{3} \\
\% \\
\end{array}$} & \multirow{2}{*}{$\begin{array}{l}\mathrm{BaCl} \\
\mathrm{TEA}\end{array}$} \\
\hline & & & $\mathrm{H}_{2} \mathrm{O}$ & $\mathrm{KCl}$ & & & & & & & \\
\hline \multirow{7}{*}{$\begin{array}{c}\text { Kampung } \\
\text { Baru } \\
\text { (1) }\end{array}$} & A & $0-14$ & 5,5 & 4,5 & 1,93 & 6,41 & 4,32 & 24,07 & 38 & 4,98 & 17,74 \\
\hline & BA & $14-28$ & 5,7 & 4,5 & 1,05 & 6,74 & 4,13 & 21,05 & 38 & 4,27 & 18,14 \\
\hline & Bt1 & $28-59$ & 5,7 & 4,1 & 0,93 & 5,26 & 3,23 & 20,88 & 32 & 3,85 & 18,95 \\
\hline & Bt2 & $59-85$ & 5,8 & 4,3 & 0,65 & 6,28 & 3,24 & 24,77 & 34 & 3,62 & 18,58 \\
\hline & Bt3 & $85-114$ & 6,0 & 4,3 & 0,58 & 5,51 & 2,97 & 18,02 & 37 & 3,67 & 15,12 \\
\hline & $\mathrm{Bt} 4$ & $114-150$ & 5,9 & 4,2 & 0,50 & & 2,80 & 20,53 & 32 & 3,92 & 16,23 \\
\hline & $\mathrm{Bt} 5$ & $150-200$ & 5,9 & 4,1 & 0,43 & 4,51 & 2,53 & 23,53 & 29 & 4,15 & 19,78 \\
\hline \multirow{5}{*}{$\begin{array}{l}\text { Sukalaksana } \\
\text { (2) }\end{array}$} & Ap & $0-15$ & 5,5 & 4,4 & 1,05 & 3,84 & 1,43 & 14,96 & 27 & 2,69 & 14,84 \\
\hline & $\mathrm{BA}$ & $15-38$ & 5,8 & 4,6 & 0,77 & 4,17 & 1,63 & 12,56 & 29 & 3,37 & 14,97 \\
\hline & Bt1 & $38-75$ & 5,7 & 4,5 & 0,55 & 3,66 & 1,61 & 13,03 & 30 & 3,36 & 12,84 \\
\hline & Bt2 & $75-126$ & 5,6 & 4,5 & 0,38 & 3,85 & 1,54 & 13,41 & 25 & 5,91 & 16,11 \\
\hline & $\mathrm{Bt} 3$ & $126-200$ & 5,7 & 4,7 & 0,34 & 3,20 & 1,49 & 15,08 & 32 & 5,15 & 10,27 \\
\hline
\end{tabular}

Total kation basa pada Pedon 1 lebih tinggi daripada Pedon 2. Hal ini dipengaruhi oleh umur pedogenik, sifat bahan induk serta curah hujan di lokasi pedon tersebut. Pedon Kampungbaru berkembang dari abu vulkanik basalt dan lingkungan yang relatif memiliki curah hujan rendah, sehingga total unsur basa lebih tinggi. Sedangkan Pedon Sukalaksana berkembang dari bahan induk dasit yang bersifat masam dan memiliki kondisi lingkungan dengan curah hujan rendah, sehingga total unsur basanya rendah. Tentu kejadian ini tidak terlepas dari tingginya proses pencucian basabasa dari profil tanah. Tingginya kandungan total kation basa pada pedon yang berasal dari abu vulkanik basalt, diduga berkaitan dengan hasil dari pelapukan mineral-mineral primer kaya unsur basa seperti plagioklas basa, piroksin dan amphibol.

Kandungan bahan organik di lokasi penelitian dipengaruhi oleh vegetasinya. Pedon Kampungbaru memiliki carbon organik lebih tinggi dari Pedon Sukalaksana, hal ini karena 
terjadi akumulasi bahan organik pada horison permukaan, serta adanya perkembangan akar dan melapuk yang dapat menyumbang bahan organik. Fenomena kandungan karbon organik nampak sejalan dengan umur pedogenik, semakin tua umur pedogenik, semakin rendah kandungan karbon organik.

Hasil pengukuran kapasitas tukar kation menunjukkan Pedon Kampungbaru lebih tinggi dibandingkan dengan Pedon Sukalaksana. Tinggi rendahnya nilai KTK Tanah di lokasi penelitian dipengaruhi oleh faktor pembentuk tanahnya seperti iklim, sifat bahan induk dan umur pedogenik. Berdasarkan pengukuran KTK dengan $\mathrm{NH}_{4} \mathrm{Oac} \mathrm{pH}$, pada Pedon Kampungbaru dengan jumlah 18-24 mEk/100 g liat, mengindikasikan adanya mineral kaolinit, smektit dan illit. Sedangkan Pedon Sukalaksana memiliki kandungan KTK 12-15 mEk/100 g liat, mengindikasikan bahwa pedon ini didominasi oleh mneral liat kaolinit, dengan demikian Pedon Sukalaksana lebih tua dan telah terjadi pelapukan lanjut dibandingkan dengan Pedon Kampungbaru.

$\begin{array}{cccr}\text { Hasil pengamatan } & \text { sifat } & \text { kimia } \\ \text { menunjukkan } & \text { bahwa } & \text { pelapukan } & \text { dan }\end{array}$ perkembangan tanah-tanah ultisol di lokasi penelitian dipengaruhi oleh faktor pembentuk tanah terutama iklim (curah hujan), umur pedogenik dan sifat bahan induk.

\subsection{Mineralogi Tanah}

\subsubsection{Mineral Fraksi Pasir}

Hasil analisis mineral fraksi pasir Pedon Kampungbaru ditemukan mineral-mineral hasil lapukan, opak dan kuarsa dalam jumlah banyak, sedangkan fragmen batuan, gelas volkanik, oligoklas, andesin dan sinidin ditemukan dalam jumlah sedikit. Selain itu juga ditemukan mineral zeolit dan konkresi besi dalam jumlah kuarsa keruh, kuarsa bening dan opak dalam jumlah banyak, hal ini menunjukkan bahwa tanah ini telah melapuk sangat lanjut. Mohr dan Van Barren (1960) mengemukakan bahwa bahan pada tanah yang sangat lanjut hanya mineral-mineral sukar lauk yang tertinggal/bertahan. Ditemukan juga mineral hasil lapukan, fragmen batuan, gelas vulkanik, oligoklas andesin, namun dalam jumlah sedikit. Kandunganopak dan kuarsa yang lebih tinggi pada Pedon Sukalaksana mencirikan pedon ini terjadi pelapukan sangat lanjut.

Pada kedua pedon tidak ditemukan perbedaan komposisi mineral yang kontras disetiap lapisan, hal ini merupakan ciri bahwa tidak terjadi penimbunan bahan induk yang berulang (Lithologic Discontinuity). Hasil analisis mineral pasir fraksi berat non opak menunjukkan Pedon Kampungbaru didominasi oleh mineral hiperstin dan augit serta sedikit hornblende hijau. Pedon Sukalaksana didominasi oleh mineral hiperstin dan augit. Mineral hornblende yang ditemukan pada Pedon Kampungbaru menunjukkan adanya pengaruh dari bahan induk yang merupakan bahan induk bersifat basa, sehingga mineralnya pun memiliki sifat yang relatif basa. Mineral fraksi berat non opak ini digunakan untuk mengetahui asosiasi mineral yang mencirikan hasil letusan suatu gunung berapi.

\subsubsection{Mineral Liat}

Hasil analisis mineral fraksi liat menunjukkan Pedon 1 dan 2 didominasi oleh mineral kaolinit (Tabel 5). Hal ini menunjukkan tingkat pelapukan lanjut pada kedua pedon (Mohr, 1972). Kaolinit merupakan mineral sekunder yang terbentuk paling akhir dalam proses pelapukan dari mineral primer (Tan, 1991). Pembentukkan kaolinit didukung oleh faktor lingkungan seperti drainase yang baik, reaksi tanah yang masam, dan pencucian basabasa yang tinggi (van Wambeke, 1992; Tardy et al., 1973 dalam Prasetyo, 2009). Pernyataan ini selaras dengan sifat fisika dan kimia yang telah diuraikan sebelumnya.

Mineral liat montmorilonit dan illit hanya ditemukan pada Pedon 1 dengan jumlah sedikit, 
sedangkan pada Pedon 2 tidak ditemukan. Mineral liat monmorilonit menyumbangkan nilai KTK yang lebih tinggi pada Pedon 1(Tabel 4). Dominansi mineral liat kaolinit tanpa mineral monmorilonit menunjukkan tingkat pelapukan lebih lanjut pada Pedon 2.

Tabel 5 Hasil Pengamatan Mineral Fraksi Liat

\begin{tabular}{|c|c|c|c|}
\hline \multirow{2}{*}{ Pedon } & \multicolumn{3}{|c|}{ Jenis Mineral Liat } \\
\hline & Kaolinit & Montmorilonit & Illit \\
\hline $\begin{array}{c}\text { Kampung Baru } \\
\text { (1) }\end{array}$ & $\mathrm{XXXX}$ & $\mathrm{x}$ & $\mathrm{x}$ \\
\hline $\begin{array}{c}\text { Sukalaksana } \\
\text { (2) }\end{array}$ & $\mathrm{XXXX}$ & - & - \\
\hline \begin{tabular}{ll}
\multicolumn{2}{l}{ Keterangan: } \\
- & : tidak ada \\
$\mathrm{x}$ & : sedikit \\
$\mathrm{xxxx}$ & : dominan $(\mathrm{l}$
\end{tabular} & yak) & & \\
\hline
\end{tabular}

\subsection{Tingkat Perkembangan Tanah}

Proses pembentukan profil tanah di lokasi penelitian telah berjalan lanjut. Ini ditandai dengan perubahan yang nyata pada horison $\mathrm{A}$, $A B$ dan B. Kedua pedon tampak secara nyata terdapat akumulasi liat di horison $\mathrm{B}$ dan membentuk horison argilik (Bt). Mineral mudah lapuk jumlahnya sangat sedikit, sedangkan mineral sukar lapuk sangat dominan.

Tidak tampak perbedaan karakteristik tanah yang nyata antara kedua pedon akibat dari kuatnya pengaruh iklim (curah hujan dan temperatur) selama proses pedogenesis berlangsung, sehingga menghasilkan produk akhir yang relatif tidak menunjukkan sifat dan karakteristik yang tidak berbeda.

Penilaian tingkat pelapukan yang berpedoman pada kriteria Travernier dan Eswaran (1972) dalam Arifin (1994), menunjukkan bahwa kedua pedon termasuk pada taraf pelapukan tahap argilik yang ditunjukkan oleh dominasi fraksi liat kristalin kaolinit, yang sudah tampak keseimbangan antara bentuk-bentuk liat dengan proses alterasi yang berlangsung.

Berdasarkan penilaian tingkat perkembangan tanah menurut Mohr dan Van Baren
(1954) dalam Hardjowigeno menunjukkan bahwa kedua pedon mempunyai derajat perkembangan tahap senile. Hal ini dicirikan dengan dekomposisi bahan organik sudah sangat sedikit dan hanya beberapa jenis mineral sukar lapuk yang terdapat dalam tanah yang masih utuh atau resisten.

\subsection{Klasifikasi Tanah}

Penetapan klasifikasi tanah mengacu kepada Key Soil Taxonomy USDA (Soil Survey Staff, 2014) yang dilakukan sampai tingkat family. Pada tingkat ordo, kedua pedon dapat diklasifikasikan ke dalam Ultisol. Hal ini berdasarkan pembentukan agrilik sebagai horizon penciri. Kedua pedon juga terdapat pada regim suhu isohipertermik, dimana suhu tanah rata-rata tahunan $>22^{\circ} \mathrm{C}$ dan perbedaan suhu rata-rata musim panas dan musim dingin $<6^{\circ} \mathrm{C}$.

Perbedaan mendasar terlihat pada kadar bahan organik yang lebih tinggi pada Pedon 1, dimana kadar C-organik > 0,9\% pada horizon permukaan argilik. Oleh karena itu, pedon dapat diklasifikasikan ke dalam Humults (Soil Survey Staff, 2014). Kedua pedon tidak menunjukkan penurunan liat sampai $20 \%$ dari jumlah maksimum sampai kedalaman, maka klasifikasi menjadi Palehumults (Soil Survey Staff, 2014; Hardjowigeno, 2003). Klasifikasi pada kategori lebih detil dengan penambahan sifat-sifat tanahnya menjadi: Typic Palehumults sangat halus, kaolinitik, isohipertermik.

Pedon 2 menunjukkan sifat tanah yang didominasi oleh pasir di lapisan permukaan sampai bawah permukaan (horizon B) (Tabel 2), hal ini diperkuat dengan nilai bobot isi tanah yang tinggi (Tabel 4). Oleh karena itu, Klasifikasi dapat dikategorikan kepada Arenic. Tidak ada sifat penciri lain selain tidak ada penambahan liat, sehingga tanah diklasifikasikan Paleudults. Klasifikasi pada kategori lebih detil dengan penambahan sifat-sifat tanahnya menjadi: 
Typic Arenic Paleudults, sangat halus, kaolinitik, isohipertermik.

Berdasarkan sistem klasifikasi FAO, Pedon Kampungbaru (Pedon 1) termasuk pada satuan tanah Humic Padzols, sedangkan Pedon Sukalaksana (Pedon 1) termasuk pada satuan tanah Haplic Podzols.

\section{KESIMPULAN}

Berdasarkan hasil dan pembahasan, maka dapat disimpulkan:

1. Ultisol yang berkembang dari bahan induk tufa dasit dan lava andesit tidak menunjukkan perbedaan sifat tanah yang kontras.

2. Tingkat pelapukan tanah ke dua pedon pada tahap senile. Perkembangan tanah kedua pedon pada tahap argilik.

3. Klasifikasi tanah pada kategori famili yaitu Pedon Kampungbaru termasuk Typic Palehumults, sangat halus, kaolinitik, isohipertermik. Sedangkan pedon Sukalaksana termasuk Arenic Paleudults, halus, kaolinitik, isohipertermik.

\section{DAFTAR PUSTAKA}

Arifin, M. 1994. Pedogenesis Andisol Berbahan Induk Abu Volkan Andesit Dan Basalt Pada Beberapa Zona Agroklimat Di Daerah Perkebunan Teh Di Jawa Barat. Desertasi. Program Pascasarjana Institut Pertanian Bogor, Bogor.

Balittanah. 2015. Prosedur Penetapan Analisis Tanah. Soil Research Institute, Bogor.

Brown, G. 1980. Tables for the Determination of $\mathrm{d}$ in $\mathrm{A}$, from $2 \mathrm{O}^{\circ}$ for the $\mathrm{Ka}$ and $\mathrm{Kb}$ radiation of copper, cobalt and iron. In Brindley, G.W and G. Brown (eds). 1980. Crystal Structures of Clay Minerals and Their X-ray Identification. Mineralogical Society. London. P. 439-475.

Hardjowigeno, S. 2003. Klasifikasi Tanah dan Pedogenesis. Ed. Revisi. Akademika. Presindo, Jakarta.
Mohr, E. C. J, and F. A. Van Baren. 1960. Tropical Soil. A Critical Study of Soil Genesis as Related to Climate, Rock and Vegetation. Les Editions. Published by The A. Monteau S. A, Bruxelles.

Peta Geologi Lembar Serang. 1991. PPPG. Bandung.

Prasetyo, B. H. 2009. Tanah merah dari berbagai bahan induk di indonesia: prospek dan strategi pengelolaannya. Jurnal Sumberdaya Lahan. 3(1): 47 60.

Prasetyo, B. H. Dan suriadikarta, D.A. 2006. Karakteristik, potensi dan teknologi pengelolaan tanah Ultisol untuk pengambangan pertanian lahan kering di Indonesia. Jurnal Litbang Pertanian. 25(2): 39 - 46.

Pusat Penelitian Tanah dan Agroklimat. 2000. Atlas Sumberdaya Tanah Eksplorasi Indonesia Skala 1:1.000.000. Pusat Penelitian Tanah dan Agroklimat, Bogor.

Soil Survey Staff. 2014. Kunci Taksonomi Tanah. Edisi Ketiga, 2015. Balai Besar Penelitian dan Pengembangan Sumberdaya Lahan Pertanian, Badan Penelitian dan Pengembangan Pertanian.

Subagyo, H., N. Suharta, dan A.B. Siswanto. 2004. Tanah-tanah pertanian di Indonesia. Dalam A. Adimihardja, L.I. Amien, F. Agus, D. Djaenudin (Ed.). Sumberdaya Lahan Indonesia dan Pengelolaannya. Pusat Penelitian dan Pengembangan Tanah dan Agroklimat, Bogor. Hal 21-66.

Subardja, D., S. Ritung, M. Anda, Sukarman, E. Suryani, dan R.E. Subandiono. 2014. Petunjuk Teknis Klasifikasi Tanah Nasional. Balai Besar Penelitian dan Pengembangan Sumberdaya Lahan Pertanian, Badan Penelitian dan Pengembangan Pertanian, Bogor.

Tan, K. H. 1991. Dasar-dasar Kimia Tanah. Penerjemah: Gunadi, D.H. Gadjah Mada University Press. Yogyakarta.

Van Reeuwijk, L.P. 2002. Procedures for Soil Analysis (6th Edition). International Soil Refference and Information Centre. Wageningen, Netherland. 
Soilrens, Volume 19 No. 2, Juli - Desember 2021

Van Wambeke, A. 1992. Soils of the Tropics.

Properties and Appraisal. McGrow-

Hill Inc. New York. 